\title{
The Gamelan in the Catholic Liturgy in Yogyakarta
}

\section{Luca Pietrosanti}

Via Ischia 21, Nettuno, 00048 Roma, Italy

Email: nanaqui2013@hotmail.com

\begin{abstract}
This paper is a brief overview of the use of the gamelan together with the polyphonic choir in the Roman rite of Holy Mass. Through the examination of repertoires, interviews and active participation in rehearsals and Masses, this work illustrates the types of compositions of liturgical music for gamelan as well as the way these compositions are used. Particular attention is addressed to some key-concepts of traditional gamelan music, such as gending, benthuk, laras, pathet, garap. It will be apparent that these concepts are adapted, firstly to integrate the gamelan with a vocal element, the choir (which is based on a western tradition) and secondly, to meet the needs of the rite of Holy Mass. Although indirectly, this paper also represents a paradigm of "Inculturation", which describes a process distinct from "Enculturation". The term "Inculturation" must be intended as "the incarnation of the Gospel in native cultures and also the introduction of these cultures into the life of the Church", so defined by the Pope John Paul II in the encyclical Slavorum Apostoli, 2nd June 1985, VI-21. Instead, with the term "Enculturation" we intend the process by which an individual learns the traditional content of a culture and assimilates its practices and values. Thus, the two words represent two different processes of assimilation of culture.
\end{abstract}

Keywords: gamelan, polyphonic choir, chatolic liturgy, liturgical songs, inculturation

\section{INTRODUCTION}

The history of the liturgical songs in Yogyakarta can be traced back to the first attempts of $\mathrm{C}$. Harjåsoebråtå to compose songs in pélog scale following the models of the Gregorian chants at the end of the 1920s. In the mid-1950s, the various experiments of introducing traditional Javanese music into the liturgy became an early inculturation program,1 thanks to the Archbishop of Semarang A. Sugyåpranåtå and his working group. At that time, no arrangements for two or more voices were made yet. After the Vatican Council II (1962-1965), a new European and Javanese committee was created, led by Father Karl Edmund Prier, 
who is also the current director of the Pusat Musik Liturgi Yogyakarta (PML). The work of the committee consisted of the creation of a liturgical repertoire that would integrate as much as possible the different musical cultures of Indonesia: not only from Java but also Sumatra, Kalimantan, Sumba (NTT - Nusa Tenggara Timur), Flores, Sulawesi, Maluku, and Papua; an extensive work culminated in the publication in 1980 of the first book of liturgical songs in Indonesian language, the Madah Bakti. Regarding the traditional music of Central Java, the work of the committee ended with the publication in 1984 of the Kidung Adi Buku Umat (book for assembly), a book of liturgical songs in Javanese, in which the main melodies are written in cipher notation, and it is intended to be sung by the assembly.

Thus, two different repertories are used in Yogyakarta, the Kidung Adi, when the Mass is in Javanese, and the Madah Bakti when the Mass is in Indonesian. Later, the PML published several complimentary books for the use of the choir or the gamelan players, in which we can find the arrangements for the choir and the notation for gamelan.

The Kidung Adi and the Madah Bakti are the references for all the modern liturgical tradition in Yogyakarta, both vocal and instrumental. The only exception is the Church of the Sacred Heart of Jesus in Ganjuran, a special place of worship, which has developed its repertoire of liturgical songs.

\section{MATERIALS AND METHODS}

This work is focused on two main aspects of the liturgical songs, vocal and instrumental. The observations about the vocal aspect are the result of research on the liturgical repertories I carried out at the Center of Liturgical Music (PMLPusat Musik Liturgi) of Yogyakarta. There, I also had the opportunity to interview the Director of the PML, Father Karl-Edmund Prier, regarding the development of the liturgical music for gamelan. Furthermore, Father Prier created a lot of the vocal arrangements for the liturgical songs and is therefore an essential referent for understanding the vocals in the liturgical composition for gamelan.

The observations on the gamelan in the liturgy as well as its relation with the choir come from more than two years of direct experience as player in liturgical cerimonies at the Parish of St. James and the Church of the Sacred Heart of Jesus in Ganjuran, both in the district of Bantul, Yogyakarta. I am specially indebted to my karawitan teacher, Bapak Didik Supriyantara, professional musician and devout Catholic, who introduced me to the world of the liturgical compositions in Yogyakarta. 
The analysis of the repertories combined with the experience in a practical application within the liturgical context represent the core of all the observations and issues addressed in this work.

\section{RESULTS}

In order to understand the phenomenon of the liturgical songs from a strictly musical point of view, the first step that needs to be discussed concerns the scales of the gamelan music. Scales have a very important practical repercussions on the vocal aspect.

Gamelan music uses two scales called pélog and sléndro; the first one has seven sounds in non-equidistant intervals; the second has five sounds in equidistant intervals. In the repertoire of liturgical gamelan music the majority of the songs are in pélog scale. There are also songs in sléndro scale, but they are far fewer in the repertoire: in the Kidung Adi there are 246 compositions in pélog scale and 43 in sléndro scale. This fact can be related to the first attempts to sing the Gregorian chants using the pélog scale, and which has become common now. All the churches I have visited have gamelan sets in pélog scale. The only church in Yogyakarta that also has a gamelan sléndro is the Church of the Holy Heart of Jesus in Ganjuran. However, the gamelan sléndro is only played at the Holy Friday Mass. Moreover, sléndro songs on this occasion are in a special modality (pathet), called sléndro Sångå tlutur. In this modality, the vocal ornaments are executed in non-equidistant intervals, thus generating a "minor effect". Javanese people confer a character of intimacy, sadness or meditation to songs in sléndro tlutur, a character that probably suits the particular moment of the Passion of Christ celebrated in the Holy Friday Mass. It seems that the non-equidistant intervals of the gamelan pélog on one hand and the songs in sléndro Sångå tlutur on the other, are someway considered appropriated to the atmosphere of solemnity of the Liturgy.

Songs in pélog scale are mostly played in two modalities: pathet nem and pathet barang. Both the gamelan music and the choir use the cipher notation, but they do not refer to the same notes. The cipher notation used in the vocal repertoire is actually a transcription of the pitches of the Do major scale (1 corresponds to "Do", 2 to "Re", and so forth). Siswanto (2015, pp. 5-7) gives us the key to read the two pélog scales through solmization. The choir tunes the "Do" on the note "6" when a song is in Pélog Nem, and on the note "3" when the song is in Pélog Barang.

At the header of the songs in the repertoires, beside the pélog scale and the pathet, we also find the corresponding note in tempered scale and the metre. Indeed, a liturgical song for gamelan can be played with or without the gamelan, a cappella or accompanied by the organ (as it is usually done in Yogyakarta). This aspect of 
the liturgical songs influences their rendition when sung together with the gamelan in terms of pitch, since the choirs are much more used to singing songs together with the organ or a cappella, rather than together with the gamelan. Indeed, despite the fact that the Churches in Yogyakarta are provided with a gamelan set, the Masses accompanied with the gamelan are events that occur at specific moments of the year. During the rehearsals for a solemn Mass, matching the pitch of the Choir to the pitch of the gamelan is a recurring issue. Although this issue can be considered just an "aesthetic" appendix, it is one of the core questions that constantly occurs in the milieu of the liturgical songs, and the PML has been carefully observing it.

For what concerns the vocal aspect, the implementation of the polyphonic choir is the result of the innovation of the Post-Conciliar Church and was largely due to the work of the PML during the mid-1960s. Many Javanese musicians composed the melodies of the liturgical songs, but nearly the entirety of the arrangements for choir were created by Father Karl Edmund Prier and Paul Widyawan, the director of the choir Vocalista Sonora (PML Yogyakarta) from 1964 until now. Actually, there have been attempts by traditional gamelan musicians to create polyphonic arrangements, however they have not been introduced in the official repertoires, due to a sort of top-down controlled process done by the PML. Despite the wide openness to the contribution of Javanese composers for the realization of liturgical songs, there is still a western "aesthetic" judgment on the works of the Javanese musicians in terms of polyphonic arrangements. However, in this sort of "one-way" approach based on the Western vocal tradition and its aesthetic, some aspects of the traditional music of central Java were incorporated to create the arrangements, as Father Prier reports in an interview he granted for this research:

«[...] Inculturation means this [Father Prier takes two papers and overlaps them partially - N/A]: here there is the West and here the East, here the liturgy, here the Javanese culture. We made experiments and elaborations by focusing on the western tradition, because there are soprano, alto, tenor and bass. The traditional gamelan music includes the use of different instruments [...] and this is the richness of this tradition [...]: when the rebab plays together with the sindhen they create a dialogue, they do not play in unison, but as a question and answer. We have taken this type of relationship from Javanese culture in order to create neither chords, neither homophony, but 'polyphony' intended in this way».

While mostly related to the European vocal tradition, the vocal arrangements also take some elements from the Javanese tradition. This is primarily the use of pentatonic scales built on the different pathet of the pélog 
scale. Secondly, they try to recreate a kind of heterophony, which in the gamelan tradition originates from the overlap of the independent melodic lines of instruments and voices. The counterpoint of the vocal arrangements is mostly imitative: the melodies of the different vocal registers repeat or present a variation on the main melody (the one assigned to the assembly) and then develop independently. The convergence of different melodies does not seem to be aimed towards the realization of chords, at least not intentionally. The imitative canon is also frequent, as well as a note against note counterpoint.

Not all the songs in the Kidung Adi and the Madah Bakti have been the object of polyphonic vocal arrangements. There are still songs only for one voice that are frequently sung in the Mass and it is not rare to listen to homophonic choirs. Indeed, we should not forget that the liturgical songs are intended to let the assembly participate in the Mass, which is one of the main aims of the PostConciliar Church. This perspective also affects the choir themselves. Each choir consists of a group of volunteers who are periodically asked to sing for an important Mass. Thus, the members of a choir are not professionally trained musicians, instead they are active members of the community who carry out a service.

Moving towards the instrumental aspect of the liturgical songs, we must say that implementation of the gamelan in the liturgy also occurred after the Vatican Council II. The work of the PML in the second half of the last century has given birth to a complete repertoire of songs that can be played with the gamelan, and the Churches I visited are all provided of a gamelan set. However, the policy of the PML has been to let each church chose when using the gamelan for a celebration. The gamelan is usually played during solemn celebrations, such as at Christmas, Easter, or for important events in a certain Church or Parish; we can also mention baptisms, consecrations and commemorations, which can occur in private places. This sort of freedom in the use of the gamelan can be explained considering two main factors:

1) liturgical songs can be played both tuning to the pitches of the tempered scale (a cappella or accompanied with the organ) or accompanied with the gamelan;

2) not always there are gamelan players within the community of a Parish, especially those who are skilled enough to play instruments such as kendhang, gendher, rebab, or gambang.

When a solemn Mass needs to be prepared, gamelan players are chosen without considering the Parish they belong to, or even without mind about their religion. During the period before a solemn mass, the gamelan group and the choir have independent rehearsals. They usually meet to practice together one or two weeks before the Mass. The fact that the liturgical songs can be accompanied with 
the organ or sung a cappella makes it possible. However, this process causes issues regarding pitch and tempo: the gamelan notes are not in the same pitch of the tempered scale; in the absence of rhythmic instruments, the tempo of the choir is generally slower that the one set by the gamelan. The impression is that the choir and gamelan are not totally blended together, rather they proceed in parallel. This is probably one of the aspects of the "slight overlapping" between the Javanese and Western musical tradition intended by Father Prier.

The only exception to this praxis in Yogyakarta is the Parish of Pugeran, where the gamelan is played every Sunday Mass at 8.00 a.m. This Parish has created a complete schedule where four gamelan groups and choirs animate one Mass in a month each. Although the use of gamelan is not strictly necessary, what I consider relevant is that it is a must in the most important religious celebrations. This fact connects the use of the gamelan as it is in its tradition to the context of the solemn catholic Masses, thus emphasizing its ritual function.

From a technical point of view, the gamelan music still keeps typical elements of its own tradition, such as musical forms (benthuk), idiosyncratic elaborations of the instruments, as well as the most common types of renditions of a song (garap). De facto, a musician who plays a liturgical song for gamelan finds himself in a familiar context. However, due to the characteristics of the liturgy, part of the gamelan tradition is not implemented. Thus, the various types of gamelan compositions (gendhing) are an adaptation of the traditional gamelan music within the liturgical context.

The traditional musical forms commonly used in the liturgy are the three so-called "Short Musical Forms" (gendhing alit): lancaran, ketawang, ladrang. During the liturgy is also frequently used one proto-gamelan form, the monggang, especially for a highly symbolic moment of the liturgy (for example, during the consecration of the bread and the wine) or processions in the place of worship. Other musical forms, that is slepeg, ayak-ayak or palaran, are present in the official repertoire, but they are not commonly used.

There are intuitive reasons for the choice of short musical forms: a short form lasts only a few minutes (even seconds), respecting the timing in the liturgy. Moreover, each of these forms has a distinctive character that suits the atmosphere of each moment in the liturgy. We have already mentioned the case of the monggang, which has a high ceremonial value even in the gamelan tradition itself

"The gamelan Monggang in the Yogyakarta kraton [...] used to be played exclusively on very solemn or festive occasions; for instance, to celebrate the Sultan's coronation or to accompany the Sultan's departure from the palace to attend important ceremonies." 
Lancaran compositions have a fast tempo and a lively character. They are usually played as an opening (pambukå), a closing (penutup) or during the offertory (pisungsung). Even compositions in ketawang and ladrang form can be used as an opening. The lancaran form is also used for musical psalm settings (kidung panglimbang-mazmur). In these cases the compositions are set in a slow tempo (irama II), which is considered more appropriate for accompaning the singing of the psalms. In these songs, the lancaran is alternated with a recitation of the verse (ayat-ayat) accompanied only by the gendèr.

Ketawang compositions have a slow tempo and a meditative character: they are the most used form in the Mass, especially in question/answer parts between the celebrant (or the lector) and the assembly, such as psalms and Alleluia. In these cases, the composition in ketawang form has only one gong cycle (gongan); the closing directly follows the opening without any repetition. In the repertorie we can find ketawang compositions for every moment of the Mass. This musical form seems to suit the liturgy tout court, maybe because of its tempo and duration. Most of the liturgical songs in Yogyakarta are set in a slow tempo. Perhaps in Javanese culture there is a connection between a slow tempo and the concept of sacred, religious.

Finally, compositions in ladrang form (which is the longest form) are usually played during long periods of the liturgy, such as the communion, or during the introduction to the Mass. Compositions in ladrang form can also be elaborated upon in various ways and present a rich and wide variety of arrangements.

Beside the traditional musical forms, in the repertoire we can also find frequently used songs that introduce new elements or variants to the traditional models, such as compositions that use elements of other regional musical traditions or irregular musical forms.

Looking at the arrangements, while the one for the choir strictly refer to the repertoires, those for gamelan present more variations. Professional musicians usually prepare a list of songs dedicated to a Mass, and it is common to vary the composition according to the taste of the specific musician. There are simply interpretative variations, such as using a slightly different tempo or a different order of the parts within a composition; but there may also be find significant variations, such as the changing of groups of notes or additional ornamentation.

Regarding the instruments' playing techniques, there is a huge range of possibilities, but only those that suit the specific liturgical moment are selected. The case of the kendhang (double-headed drum) is exemplary, because this instrument influences both the types of playing techniques of the other instruments and the resulting rendition of the composition. During the Mass, there is the opportunity to play all the three types of kendhang, but it depends on the 
specific moment of the liturgy. The opening, the closing, the offertory and the communion are appropriate moments to play the kendhang batangan (the medium sized drum). The kendang kalih (the combination of the smallest and the biggest sized drum) is preferred for the other moments, such as for Psalms or Alleluia.

\section{DISCUSSION}

Liturgical songs for gamelan and choir are a good example of the convergence of very different cultures, and an interesting phenomenon from the point of view of the ethnomusicologist. We must remember, indeed, that Ethnomusicology consists not only of the study of popular or tribal music, but also includes the study of the syncretic dynamics between different musical cultures.

Despite its actual limits, the process of inculturation has created a lively environment and opened new perspectives to gamelan traditional music. Even if the implementation of the choir on top of pre-existing traditional structures still represents something far from the Javanese traditional culture, it has been received positively. The western musical tradition has also inspired the creation of new types of compositions that still keep the spirit of the gamelan tradition. In combination, these elements do not compromise the Javanese musical culture, rather they somehow show the strengthening of a musical tradition capable of reinventing itself and preserving its own distinctive characteristics.

\section{REFERENCES}

Costitution on the Sacred Liturgy Sacrosantum Concilium, 4th December 1963.

Costitution on the Sacred Liturgy Sacrosantum Concilium, chapter II, 48.

Harsi \& Sunarto, Mengenal Sosok C. Harjasoebrata, Indie Book Corner, 2014.

Pearlman Marc, The term Karawitan, in Balungan, vol. 5 n. 1 winter/spring 1991.

PML, Madah Bakti - buku doa dan nyanyikan, edited by PML Yogyakarta, PML Yogyakarta press, 1980.

PML, Kidung Adi - Buku Umat, edited by PML Yogyakarta, PML Yogyakarta press, 1984.

PML, Kidung Adi - buku kor, Jilid I-IV, edited by PML Yogyakarta PML Yogyakarta press, 2013 (8th ed.).

PML, Kidung Adi - buku balungan, Jilid I-III, edited by PML Yogyakarta, PML Yogyakarta press, 2013 (8th ed.).

PML, Madah Bakti - Buku kor campur dengan iringan gamelan, edited by PML Yogyakarta, PML Yogyakarta press, 2013 (8th ed.).

PML, Madah Bakti - buku iringan gamelan, edited by PML Yogyakarta, PML Yogyakarta press, 2013 (8th ed.).

PML, Madah Bakti - buku iringan gamelan, edited by PML Yogyakarta, PML Yogyakarta press, 2013 (8th ed.).

Pope John Paul II, encyclical Slavorum Apostoli, 2nd June 1985. 
Prier K. E., Perjalanan Musik Gareja Katolik Indonesia Tahun 1957-2007, PML, Yogyakarta press, 2008.

Saridal Chris, Kidungan Katur Tyas Dalem Sri Yesus Ingkang Mahasuci - Kanthi Iringan Gendhing, Gareja Tyas Dalem Ganjuran, Sumbermulya, Bambangglipuro, Bantul, Daerah Istimewa Yogyakarta, 2000.

Saridal Chris, Kidungan Jemuah Adi - Gendhing-gendhing Jawi Slendro 9, Kacawisaken Dening, Seksi Pendidikan \& Kebudayaan kangge kabetahan Liturgi.

Siswanto M., Tutnunan Karawitan II, PML Yogyakarta press, 2015.

Soedarsono R. M., Ritual Performing Arts in the Court of Yogyakarta Past and Present, in Urban Culture Research vol. 1, University of Gadja Mada Yogyakarta, 2003.

Supanggah Rahayu, Gatra: A Basic Concept of Traditional Javanese Gending, in Balungan voll. 9-10, 2005. 